Professor Manuela Rozalia GABOR, PhD

E-mail: manuela.gabor@umfst.ro

Associate Professor Mihaela KARDOS, PhD

E-mail: mihaela.kardos@umfst.ro

Department of Economic Sciences, "G. E. Palade" University of

Medicine, Pharmacy, Sciences and Technology of Târgu Mures

Professor Nicoleta CRISTACHE, PhD

Department of Business Administration,

"Dunărea de Jos" University of Galați

E-mail: nicoleta.cristache@ugal.ro

Professor Marian NASTASE, PhD

Department of Management

The Bucharest University of Economic Studies

E-mail: marian.nastase@man.ase.ro

Lecturer Ioan-Radu PETRARIU, PhD

Department of International Relations,

The Bucharest University of Economic Studies

E-mail: radu.petrariu@rei.ase.ro

\title{
DYNAMIC ANALYSIS OF TOURISM COMPETITIVENESS OF THE EUROPEAN COUNTRIES BASED ON DISCRIMINANT STATISTICAL ANALYSIS
}

\begin{abstract}
The measure of destination competitiveness has received increasing attention in literature. The competitiveness and management of tourism destination is of great importance as countries strive for a bigger market share and the transition from mass tourism to a new age of tourism calls for a customized approach to the specificities of tourism. In this context, the paper aims to conduct a dynamic analysis on the tourism destination management and competitiveness of European countries, using the discriminant analysis. The analysis is based on the 14 pillars described in the Travel \& Tourism Competitiveness Report for all European countries, considering reference years 2011 and 2019. Our research introduces new characteristics for dependent variable in discriminant analysis: the geographical position (East/West/Central), member/non- member of the European Union, ex-communist/democratic country, developed/developing country. It is also the first research to dynamically analyze the TTCI pillar(s) that discriminate better taking into consideration the above-mentioned countries' characteristics.
\end{abstract}

Keywords: discriminant analysis, dynamic analysis, European countries, competitiveness index, tourism.

JEL Classification: C11, C61, C82, L83, P52

DOI: $10.24818 / 18423264 / 55.3 .21 .07$ 
Manuela Rozalia Gabor, Mihaela Kardos, Nicoleta Cristache,Marian Nastase, Ioan-Radu Petrariu

\section{Introduction}

Tourism has become one of the most important industries in the world, and its economic impact is vital for many countries (Fayed \& Fletcher, 2002). Tourism has experienced constant growth and diversification to become one of the largest and fastest growing industries (Hanafiah et al., 2016a) and over the recent years (except for the pandemic) has become one of the sectors generating the most added value (Sanchez \& Lopez, 2015). Therefore more attention has been given to the management of tourism destination and country brand building.

Destination competitiveness concept and measurement have become of great interest in the scientific literature on tourism (Cracolici et al., 2008). The competitiveness and management of tourism destinations are important, as countries strive for a bigger market share (Gooroochurn and Sugiyarto, 2005) and the transition from mass tourism to a new age of tourism calls for a customized approach to the specific attitude and needs of tourism (Cracolici et al., 2008).

From the perspective of tourism destination management, Travel \& Tourism Competitiveness Index (TTCI) is expected to be an instrument in explaining and predicting the tourism performance of receiving countries (Mazanec and Ring, 2011). TTCI is considered an excellent contributor to tourism competitiveness measurement and understanding (Hanafiah et al., 2016a) and an important tool for country/destination brand and tourism destination management.

In 2017, international tourist arrivals recorded the highest growth in all years since 2010 according to UNWTO Tourism Highlights 2018 edition. All regions witnessed growth in both international tourist arrivals and receipts, the biggest in Africa $(+9 \%)$ and Europe $(+8 \%)$. In a rapid changing economy, facing political changes and natural disasters around the world, Europe records $51 \%$ of worldwide international tourist arrivals (672 million) and $39 \%$ of international tourist receipts (519 US\$ billion), according to UNWTO. In 2017 compared to 2016 growth in arrivals was slightly faster in emerging economies $(+4.8 \%)$ than in advanced ones $(+3.7 \%)$.

In most developed and developing countries, tourism industry has been identified as a significant income producer (Hanafiah et al., 2016a). Therefore, the quantitative analysis of competitiveness in tourism, using different statistical tools is highly important and necessary to conduct a research from different perspectives.

The paper aims to conduct a dynamic analysis comparatively for 2019 and 2011 of the European countries' tourism competitiveness using the discriminant analysis. The analysis is based on the 14 pillars described in Travel \& Tourism Competitiveness Reports 2011 and 2019, beyond the downturn by the World Economic Forum taking into consideration only the European countries.

Our research introduces new characteristics of the countries in the panel (the 42 European countries), respectively:

- the geographical position: East/ Central/ West European country;

- member or non-member of the European Union;

- ex-communist or democratic country; 
Dynamic Analysis of Tourism Competitiveness of the European Countries Based on Discriminant Statistical Analysis

- developed or developing country.

In Figure 1 we structured all dynamic changes for the 42 European countries, comparatively for 2011 and 2019 and we marked the decreasing of TTCI rank with red color and the increasing with blue color.

\begin{tabular}{|c|c|c|c|c|c|c|c|c|c|c|c|}
\hline & $\begin{array}{l}\text { Rank } \\
2011\end{array}$ & $\begin{array}{l}\text { Rank } \\
2019\end{array}$ & $2019 / 2011$ & & $\begin{array}{l}\text { Rank } \\
2011\end{array}$ & $\begin{array}{l}\text { Rank } \\
2019\end{array}$ & & & $\begin{array}{l}\text { Rank } \\
2011\end{array}$ & $\begin{array}{l}\text { Rank } \\
2019\end{array}$ & \\
\hline Albania & 71 & 86 & -15 & Germany & 2 & 3 & -1 & Norway & 20 & 20 & 0 \\
\hline Armenia & 90 & 79 & 11 & Greece & 29 & 25 & 4 & Poland & 49 & 42 & 7 \\
\hline Austria & 4 & 11 & -7 & Hungary & 38 & 48 & -10 & Portugal & 18 & 12 & 6 \\
\hline $\begin{array}{l}\text { Belgium } \\
\text { Bosnia \& }\end{array}$ & 23 & 24 & -1 & Iceland & 11 & 30 & -19 & $\begin{array}{l}\text { Romania } \\
\text { Russian }\end{array}$ & 63 & 56 & 7 \\
\hline Hertegovi & 97 & 105 & -8 & Ireland & 21 & 26 & -5 & Federation & 59 & 39 & 20 \\
\hline Bulgaria & 48 & 45 & 3 & Italy & 27 & 8 & 19 & Serbia & 82 & 83 & -1 \\
\hline Croatia & 34 & 27 & 7 & Latvia & 51 & 53 & -2 & Slovenia & 33 & 36 & -3 \\
\hline $\begin{array}{l}\text { Cyprus } \\
\text { Czech }\end{array}$ & 24 & 44 & -20 & Lithuania & 55 & 59 & -4 & Slovak Republic & 54 & 60 & -6 \\
\hline Republic & 31 & 38 & -7 & Luxembourg & 15 & 23 & -8 & Spain & 8 & 1 & 7 \\
\hline Denmark & 16 & 21 & -5 & Macedonia. FYR & 76 & 101 & -25 & Sweden & 5 & 22 & -17 \\
\hline Estonia & 25 & 46 & -21 & Malta & 26 & 35 & -9 & Switzerland & 1 & 10 & -9 \\
\hline Finland & 17 & 28 & -11 & Moldova & 99 & 103 & -4 & Turkey & 50 & 43 & 7 \\
\hline France & 3 & 2 & 1 & Montenegro & 36 & 67 & -31 & Ukraine & 85 & 78 & 7 \\
\hline Georgia & 73 & 68 & 5 & Netherlands & 14 & 15 & -1 & United Kingdom & 7 & 6 & 1 \\
\hline
\end{tabular}

Figure 1.The dynamic evolution 2019/2011 of the TTCI for European countries

(Source: made by the authors based on the Travel \& Tourism Competitiveness Reports

2011, 2019)

This research also feels the gap in the literature being the first which dynamically analyses the associations/correlations inside of pillars of TTCI but also considers which pillars discriminate better taking into consideration the characteristics mentioned $f$ above for the two years, 2011 and 2019. Our research aims to highlight if for the considered period there are statistically significant differences by using a less applied method and to fill in the theoretical backgrounds of the competitiveness analysis taking into considerations the above mentioned characteristics of the dependent variables for the discriminant analysis. The independent variables for the discriminant analysis were all 14 pillars of Travel and Tourism Competitiveness Index (TTCI).

The research fills in previous results (Gabor, Oltean and Conțiu, 2012; Gabor and Oltean, 2017) and using other statistical methods (discriminant analysis) studies thoroughly and emphasizes other important aspects related to measuring and ranking tourism competitiveness in European countries. Based on its results, the paper formulates some recommendations for a better tourism destination management and destination brand, especially for Romania in the European context. 
Manuela Rozalia Gabor, Mihaela Kardos, Nicoleta Cristache,Marian Nastase, Ioan-Radu Petrariu

\section{Literature review}

In international literature there are an important number of papers discussing tourism competitiveness impact based on the TTCI. There are a lot of well-known competitiveness models, such as Porter's competitiveness forces/determinants, Ritchie \& Crouch destination competitiveness, WES model, etc. but all of them also have strengths and weaknesses or contradictory results.

One of the first innovative approaches for measuring tourism competitiveness was made by Gooroochenen and Sugiyarta (2005) using eight main indicators: price, openness, technology, infrastructure, human tourism, social development, environment, and human resources, for over 200 countries. Also, in 2008, Cracolici et al. applied parametrical and non-parametrical statistics, a stochastic production function and DEA method to study tourism competitiveness.

In 2010, Das and Dirienzo took into consideration another important variable, the role of consumption in a country' ability to compete globally in the tourism industry by using both 2008 TTCI and 2006 Consumption perception Index.

Then, the research of Gabor, Oltean \& Contiu, 2012 using PCA method and cluster analysis on all 42 European countries highlighted the clustering as follows:

- for the European Union countries: Nordic countries; countries that predominantly practice sun lust tourism; former communist countries; a cluster bringing together two atypical countries, namely Poland and Romania and a combined group of Nordic countries and former communist countries.

- for the Non-European Union countries: countries of the former Republics of the Soviet Union; countries which are among the top developed countries and former communist countries.

In 2015, Lee also used the TTCI from World Economic Forum 2013 Report and emphasized the importance of government quality in tourism competitiveness. Also, in 2017, Omkar et al., used TTCI pillars on cross-country panel data model.

In 2017, Gabor and Oltean using non-parametric statistics pointed out that there is negative correlation of price competitiveness with air transport and ground transport for all European countries. Also, there are positive correlations of air transport and ICT infrastructure with majority of the pillars for all European countries. By applying statistical tests (Kolmogorov - Smirnov, U Mann Whitney and Kruskal - Wallis) for each subindex of TTCI the authors pointed out that there are differences between European countries ranks.

Even the majority of papers emphasize the importance of governments and/or travel and transport service in tourism competitiveness (Khan et al., 2017), there are authors having different approaches, i.e. Dias (2017) emphasized the reliability of environmental sustainability index implemented by the TTCI using exploratory and confirmatory factor analysis. Also, Ritchie \& Crouch (2000) state 
Dynamic Analysis of Tourism Competitiveness of the European Countries Based on Discriminant Statistical Analysis

that the fundamental product in tourism competitiveness is destination experience; competition, therefore, centered on the destination. There are also changes in approach: from the market oriented to sustainability oriented (Mendola and Volo, 2017).

\section{Methodology}

The TTCI aims to measure factors and policies working as incentives for developing travel and tourism sector in different countries (Gabor et al., 2012; Gabor and Oltean, 2017) and it is composed by three (for 2011) respectively four (for 2019) broad categories of variables that facilitate or drive travel and tourism competitiveness. From 2011 to 2019 the TTCI structure had changed. Table 1 emphasises all these aspects. Each of the subindices is composed by several pillars of TTCI, a total of 14 (Gabor and Oltean, 2017) for both 2011 and 2019.

Table 1. The structure of the TTCI in 2011 and 2019 according to WEF 2011 TTCI 2019 TTCI

\begin{tabular}{|c|c|c|c|}
\hline & & & \\
\hline Sub-index & Pillars & Pillars & Sub-index \\
\hline \multirow{5}{*}{$\begin{array}{c}\text { A.T \& T } \\
\text { Regulatory } \\
\text { Framework }\end{array}$} & $\begin{array}{l}\text { 1. Policy rules and } \\
\text { regulations }\end{array}$ & 1. Business environment & \multirow{5}{*}{$\begin{array}{l}\text { A. Enabling } \\
\text { Environment }\end{array}$} \\
\hline & $\begin{array}{l}\text { 2. Environmental } \\
\text { sustainability }\end{array}$ & 9. ICT readiness & \\
\hline & 3. Safety and security & 3. Safety and security & \\
\hline & 4. Health and hygiene & 4. Health and hygiene & \\
\hline & $\begin{array}{l}\text { 5. Prioritization of travel } \\
\text { \& tourism }\end{array}$ & $\begin{array}{l}\text { 11. Human resources and } \\
\text { labor market }\end{array}$ & \\
\hline \multirow{5}{*}{$\begin{array}{c}\text { B.T \& T } \\
\text { Environment } \\
\& \\
\text { Infrastructure }\end{array}$} & $\begin{array}{l}\text { 6. Air transport } \\
\text { infrastructure }\end{array}$ & $\begin{array}{l}\text { 6. Air transport } \\
\text { infrastructure }\end{array}$ & \multirow{3}{*}{$\begin{array}{c}\text { C. } \\
\text { Infrastructure }\end{array}$} \\
\hline & $\begin{array}{l}\text { 7. Ground transport } \\
\text { infrastructure }\end{array}$ & $\begin{array}{l}\text { 7. Ground and port } \\
\text { infrastructure }\end{array}$ & \\
\hline & 8. Tourism infrastructure & $\begin{array}{l}\text { 8. Tourism service } \\
\text { infrastructure }\end{array}$ & \\
\hline & 9. ICT infrastructure & $\begin{array}{l}\text { 2. Environmental } \\
\text { sustainability }\end{array}$ & \multirow{4}{*}{$\begin{array}{c}\text { B.T \& T } \\
\text { Policy and } \\
\text { Enabling } \\
\text { Conditions }\end{array}$} \\
\hline & $\begin{array}{l}\text { 10. Price competitiveness } \\
\text { in the } \mathrm{T} \& \mathrm{~T} \text { industry }\end{array}$ & 10. Price competitiveness & \\
\hline \multirow{4}{*}{$\begin{array}{l}\text { C. T \& T } \\
\text { Human, } \\
\text { Cultural \& } \\
\text { Natural } \\
\text { Resources }\end{array}$} & 11. Human resources & $\begin{array}{l}\text { 5. Prioritization of travel } \\
\text { \& tourism }\end{array}$ & \\
\hline & $\begin{array}{l}\text { 12. Affinity for travel \& } \\
\text { tourism }\end{array}$ & $\begin{array}{l}\text { 12. International } \\
\text { Openness }\end{array}$ & \\
\hline & 13. Natural resources & 13. Natural resources & \multirow{2}{*}{$\begin{array}{c}\text { D. Natural } \\
\text { and Cultural } \\
\text { Resources }\end{array}$} \\
\hline & 14. Cultural resources & $\begin{array}{l}\text { 14. Cultural resources and } \\
\text { business travel }\end{array}$ & \\
\hline
\end{tabular}

(Source: made by the authors based on the Travel \& Tourism Competitiveness Reports)

To analyse which of the pillars (the independent variables) differentiate the best the classification of countries according to the competitiveness score, we 
Manuela Rozalia Gabor, Mihaela Kardos, Nicoleta Cristache,Marian Nastase, Ioan-Radu Petrariu

applied discriminant analysis grouping the 42 European countries according to the above-mentioned characteristics (dependent variables).

As explanatory method of data analysis, we can define discriminant analysis as a method of forecasting the linear relation between a non-diametric dependent variable type dichotomous or multichotomies and linear combinations of several metric independent variables (Gabor, 2016; Gabor, 2010). This method applies to a population of individuals defined by continuous or category variables that are a priori (or even naturally) divided in groups. In this research we use both groups, when dichotomous variables are comprised in the study and the multiple discriminant analysis when the dependent variable has several categories (Gabor, 2016; Gabor, 2010).

For discriminant analysis the SPSS 23.0 software was used. The discriminant analysis model is given by equation (1) (Spircu et al., 1994):

$$
\mathrm{D}=\mathrm{b}_{0}+\mathrm{b}_{1} \mathrm{X}_{1}+\mathrm{b}_{2} \mathrm{X}_{2}+\mathrm{b}_{3} \mathrm{X}_{3}+\ldots .+\mathrm{b}_{\mathrm{n}} \mathrm{X}_{\mathrm{n}}
$$

where $(\mathrm{D}-$ value of the determinant

bk - discriminant coefficients,

$\mathrm{Xk}$ - independent variables.

The motivation for using this method of data analysis is based on the fact that it is the only one to be approached from two methodological perspectives, both as explanatory method and descriptive method, basically having two purposes (Spircu et al., 1994):

- a descriptive one (searching an as low as possible number of explanatory variables to express "best" the separation of individuals in classes) and

- an explanatory purpose, of forecast (consisting of checking to what extent a certain individual, still ungrouped, is similar to individuals in a certain class, and if this similitude exists, to decide its distribution to the class concerned).

\section{Results}

In this section we present the results compared for 2011 and 2019. In Table 2 (for 2011) and Table 3(for 2019) are presented the results of test of equality of group means. The columns represent the dependent variables of the discriminant analysis and the lines represent the independent variables, respectively the 14 pillars of the TTCI grouped according to the sub-indices specific for each year. With red are marked the pillars who statistically significant discriminate between groups.

For 2011 (Table 2) there are some variables without any contribution to the discriminations between the European countries. The affinity for travel \& tourism is the single pillar not discriminating for any kind of groups. The safety and security, the prioritization of travel and tourism, the price and competitiveness in the travel and tourism industry and natural resources do not discriminate for group member or non-member of EU. The health and hygiene does not discriminate for group ex-communist or democratic countries.

For 2019 (Table 3) for members or non-members of EU, the variables 
Dynamic Analysis of Tourism Competitiveness of the European Countries Based on Discriminant Statistical Analysis

(pillars) not discriminating between the countries are: business environments, human resources and labour market, prioritization of travel and tourism, price competitiveness and air transport infrastructure.

Table 2. Tests of Equality of Group Means for TTCI 2011

\begin{tabular}{|c|c|c|c|c|c|c|c|c|c|c|c|c|}
\hline & \multicolumn{3}{|c|}{$\begin{array}{c}\text { Member of } \\
\text { EU/non- member } \\
\text { of EU }\end{array}$} & \multicolumn{3}{|c|}{$\begin{array}{c}\text { Ex-communist/ } \\
\text { democratic } \\
\text { countries } \\
\end{array}$} & \multicolumn{3}{|c|}{$\begin{array}{c}\text { Developed } \\
\text { /developing } \\
\text { countries } \\
\end{array}$} & \multicolumn{3}{|c|}{$\begin{array}{c}\text { East/Central/ } \\
\text { West European } \\
\text { countries } \\
\end{array}$} \\
\hline & 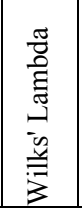 & 工 & $\dot{\vec{D}}$ & 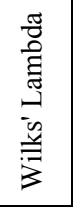 & 工 & $\dot{00}$ & 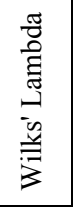 & 工 & $\dot{\ddot{n}}$ & 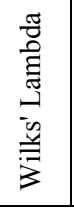 & 厌 & $\dot{\ddot{D}}$ \\
\hline \multicolumn{13}{|c|}{ A. T \& T Regulatory Framework } \\
\hline $\begin{array}{l}\text { Policy rules } \\
\text { and regul. }\end{array}$ & .891 & 4.896 & .033 & .698 & 17.267 & .000 & .713 & 16.089 & .000 & .593 & 13.400 & .000 \\
\hline $\begin{array}{l}\text { Environmental } \\
\text { sustain. }\end{array}$ & .765 & 12.315 & .001 & .627 & 23.774 & .000 & .549 & 32.831 & .000 & .458 & 23.110 & .000 \\
\hline $\begin{array}{l}\text { Safety and } \\
\text { security }\end{array}$ & .910 & 3.957 & .054 & .640 & 22.525 & .000 & .520 & 36.932 & .000 & .480 & 21.137 & .000 \\
\hline $\begin{array}{l}\text { Health \& } \\
\text { Hygiene }\end{array}$ & .875 & 5.694 & .022 & .936 & 2.734 & .106 & .872 & 5.891 & .020 & .820 & 4.280 & .021 \\
\hline $\begin{array}{l}\text { Prioritization } \\
\text { of T \& T }\end{array}$ & .958 & 1.764 & .192 & .687 & 18.240 & .000 & .674 & 19.306 & .000 & .770 & 5.821 & .006 \\
\hline \multicolumn{13}{|c|}{ B. Business environment and infrastructure } \\
\hline $\begin{array}{l}\text { Air transport } \\
\text { infrastruct. }\end{array}$ & .868 & 6.069 & .018 & .206 & 154.507 & .000 & .231 & 132.82 & .000 & .290 & 47.761 & .000 \\
\hline $\begin{array}{l}\text { Ground } \\
\text { transport } \\
\text { infrastruct. }\end{array}$ & .639 & 22.566 & .000 & .501 & 39.812 & .000 & .473 & 44.601 & .000 & .472 & 21.813 & .000 \\
\hline $\begin{array}{l}\text { Tourism } \\
\text { infrastruct. }\end{array}$ & .777 & 11.475 & .002 & .723 & 15.308 & .000 & .679 & 18.890 & .000 & .560 & 15.328 & .000 \\
\hline $\begin{array}{l}\text { ICT } \\
\text { infrastruct. }\end{array}$ & .734 & 14.47 & .000 & .522 & 36.565 & .000 & .436 & 51.723 & .000 & .341 & 37.767 & .000 \\
\hline $\begin{array}{l}\text { Price } \\
\text { compet.in the } \\
\text { T\&T ind. }\end{array}$ & .939 & 2.58 & .116 & .488 & 42.034 & .000 & .482 & 42.923 & .000 & .475 & 21.587 & .000 \\
\hline \multicolumn{13}{|c|}{ C. Human, cultural, and natural resources } \\
\hline $\begin{array}{l}\text { Human } \\
\text { resources }\end{array}$ & .907 & 4.121 & .049 & .475 & 44.151 & .000 & .407 & 58.270 & .000 & .432 & 25.668 & .000 \\
\hline $\begin{array}{l}\text { Affinity for } \\
\text { T\&T }\end{array}$ & .977 & .946 & .337 & .954 & 1.924 & .173 & .961 & 1.630 & .209 & .936 & 1.325 & .278 \\
\hline Natural res & .942 & 2.467 & .124 & .877 & 5.634 & .023 & .867 & 6.119 & .018 & .821 & 4.265 & .021 \\
\hline Cultural res. & .770 & 11.951 & .001 & .536 & 34.565 & .000 & .583 & 28.662 & .000 & .497 & 19.736 & .000 \\
\hline
\end{tabular}

(Source: our research results)

Comparatively with 2011, only two variables remain without any discriminations for EU members countries or not: the prioritization of travel and tourism and the price competitiveness. For groups ex-communist/democratic countries, developed/developing countries, East/Central/West European countries the pillars without any discrimination contribution are the health and hygiene and 
Manuela Rozalia Gabor, Mihaela Kardos, Nicoleta Cristache,Marian Nastase, Ioan-Radu Petrariu

the natural resources. For ex-communist or democratic countries the health and hygiene is the pillar without statistics significance for discrimination both 2011 and 2019.

Table 3. Tests of Equality of Group Means for TTCI 2019

\begin{tabular}{|c|c|c|c|c|c|c|c|c|c|c|c|c|}
\hline & \multicolumn{3}{|c|}{$\begin{array}{c}\text { Member of } \\
\text { EU/non- } \\
\text { member EU }\end{array}$} & \multicolumn{3}{|c|}{$\begin{array}{c}\text { Ex-communist/ } \\
\text { democratic } \\
\text { countries }\end{array}$} & \multicolumn{3}{|c|}{$\begin{array}{c}\text { Developed/ } \\
\text { Developing } \\
\text { countries }\end{array}$} & \multicolumn{3}{|c|}{$\begin{array}{c}\text { East/Central/ West } \\
\text { countries }\end{array}$} \\
\hline & 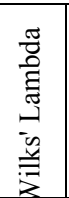 & 工 & $\stackrel{\infty}{\dot{\infty}}$ & 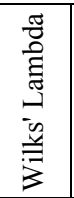 & 工 & $\stackrel{\infty 00}{n}$ & 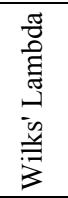 & 工 & $\frac{00}{\infty}$ & 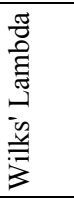 & 山 & $\dot{00}$ \\
\hline \multicolumn{13}{|c|}{ A. Enabling Environment } \\
\hline $\begin{array}{l}\text { Business } \\
\text { environ. }\end{array}$ & .977 & .955 & .344 & .662 & 20.410 & .000 & .631 & 23.382 & .000 & .639 & 11.021 & .000 \\
\hline $\begin{array}{l}\text { Safety \& } \\
\text { security }\end{array}$ & .868 & 6.074 & .018 & .905 & 4.195 & .047 & .779 & 11.373 & .002 & .764 & 6.024 & .005 \\
\hline $\begin{array}{l}\text { Health } \\
\text { hygien }\end{array}$ & .871 & 5.915 & .020 & .999 & .057 & .813 & .982 & .716 & .402 & .953 & .960 & .392 \\
\hline $\begin{array}{l}\text { HR\&lab } \\
\text { market }\end{array}$ & .945 & 2.311 & .136 & .636 & 22.893 & .000 & .530 & 35.515 & .000 & .543 & 16.429 & .000 \\
\hline ICT readin. & .716 & 15.879 & .000 & .589 & 27.960 & .000 & .479 & 43.450 & .000 & .446 & 24.246 & .000 \\
\hline \multicolumn{13}{|c|}{ B. T \& T Policy and Enabling Conditions } \\
\hline $\begin{array}{l}\text { Prioritization } \\
\text { of T \& T }\end{array}$ & .962 & 1.573 & .217 & .641 & 22.396 & .000 & .658 & 20.799 & .000 & .751 & 6.457 & .004 \\
\hline Int. Openn. & .524 & 36.384 & .000 & .671 & 19.576 & .000 & .672 & 19.530 & .000 & .623 & 11801 & .000 \\
\hline $\begin{array}{l}\text { Price } \\
\text { competitiv }\end{array}$ & .942 & 2.441 & .126 & .402 & 59.434 & .000 & .338 & 78.348 & .000 & .334 & 38.896 & .000 \\
\hline $\begin{array}{l}\text { Environ. } \\
\text { sustainab. }\end{array}$ & .861 & 6.475 & .015 & .832 & 8.088 & .007 & .753 & 13.101 & .001 & .627 & 11.617 & .000 \\
\hline \multicolumn{13}{|c|}{ C. Infrastructure } \\
\hline $\begin{array}{l}\text { Air transp. } \\
\text { infrastruct }\end{array}$ & .940 & 2.532 & .119 & .271 & 107.685 & .000 & .340 & 77.585 & .000 & .333 & 38.996 & .000 \\
\hline $\begin{array}{l}\text { Ground \& } \\
\text { port infrastr }\end{array}$ & .611 & 25.476 & .000 & .557 & 31.854 & .000 & .514 & 37.779 & .000 & .465 & 22.449 & .000 \\
\hline $\begin{array}{l}\text { Tourist } \\
\text { service infr }\end{array}$ & .782 & 11.145 & .002 & .658 & 20.748 & .000 & .648 & 21.733 & .000 & .609 & 12.500 & .000 \\
\hline \multicolumn{13}{|c|}{ D. Natural and Cultural Resources } \\
\hline Natural res. & .907 & 4.111 & .049 & .920 & 3.498 & .069 & .912 & 3.875 & .056 & .881 & 2.633 & .085 \\
\hline $\begin{array}{l}\text { Cultural res. } \\
\text { \& bus travel }\end{array}$ & .873 & 5.827 & .020 & .710 & 16.373 & .000 & .743 & 13.836 & .001 & .709 & 8.007 & .001 \\
\hline
\end{tabular}

(Source: our research results)

In Tables 4 (for 2011) and Table 5 (for 2019) are presented the standardized and unstandardized canonical discriminant function coefficients, necessary to compare the discriminant functions for each group of the 42 European countries. By standardizing (dividing by the standard deviation within the groups), according to the data from the Tables 4 and 5 - standardized canonical discriminant 
Dynamic Analysis of Tourism Competitiveness of the European Countries Based on Discriminant Statistical Analysis

function coefficients - the expressions of the discriminant functions for TTCI' pillars for 2011 and 2019 can be determined. With red are marked the most important discriminant variables for each group according to Structure matrix results from SPSS.

Table 4. Standardized and Unstandardized Canonical Discriminant Function Coefficients for TTCI 2011

\begin{tabular}{|c|c|c|c|c|c|c|c|c|c|c|}
\hline \multirow{3}{*}{ Variables } & \multicolumn{5}{|c|}{$\begin{array}{c}\text { Canonical Discriminant Function } \\
\text { Coefficients }\end{array}$} & \multicolumn{5}{|c|}{$\begin{array}{c}\text { Standardized Canonical Discriminant } \\
\text { Function Coefficients }\end{array}$} \\
\hline & \multirow{2}{*}{ 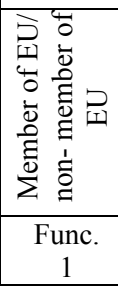 } & \multirow{2}{*}{ 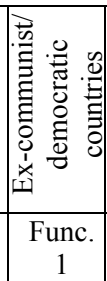 } & \multirow{2}{*}{ 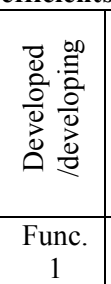 } & \multicolumn{2}{|c|}{ 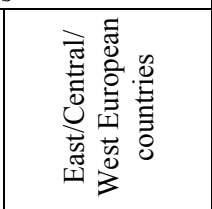 } & \multirow{2}{*}{ 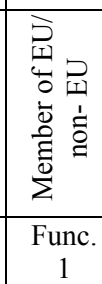 } & \multirow{2}{*}{ 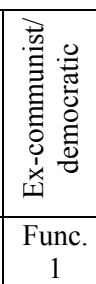 } & \multirow{2}{*}{ 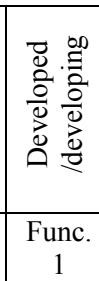 } & \multicolumn{2}{|c|}{ 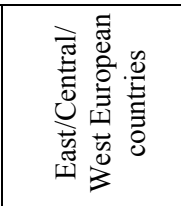 } \\
\hline & & & & $\begin{array}{c}\text { Func. } \\
1\end{array}$ & $\begin{array}{c}\text { Func. } \\
2\end{array}$ & & & & Func. 1 & $\begin{array}{c}\text { Func } \\
2\end{array}$ \\
\hline \multicolumn{11}{|c|}{ A. T \& T Regulatory Framework } \\
\hline $\begin{array}{l}\text { Policy rules \& } \\
\text { regulations }\end{array}$ & -.273 & .502 & -.160 & .412 & -.649 & -.124 & .202 & -.065 & .154 & -.244 \\
\hline Environ sust & 2.553 & 1.085 & 1.118 & 1.184 & -.782 & 1.344 & .517 & .499 & .488 & -.322 \\
\hline Safety & -1.117 & .261 & .967 & & .292 & -.648 & .127 & .424 & .366 & .124 \\
\hline Health $c$ & .529 & -.023 & .294 & & 1.728 & .290 & -.013 & .161 & .163 & .928 \\
\hline $\begin{array}{l}\text { Prioritiz } \\
\text { of T \& } 1\end{array}$ & .290 & 1.076 & .939 & .568 & .182 & .204 & .640 & .554 & .362 & .116 \\
\hline (Constant) & -10.046 & -14.193 & -16.467 & -17.165 & -6.071 & & & & & \\
\hline \multicolumn{11}{|c|}{ B. Business environment and infrastructure } \\
\hline $\begin{array}{l}\text { Air transport } \\
\text { infrastructure }\end{array}$ & -.559 & 1.634 & 1.205 & 682 & -1.353 & -.606 & .862 & .675 & .433 & -.858 \\
\hline $\begin{array}{l}\text { Grot } \\
\text { trans }\end{array}$ & 1.180 & .125 & -.019 & -.204 & .064 & 1.148 & .107 & -.016 & -.172 & .054 \\
\hline Touri & .454 & .121 & .171 & .164 & .787 & .511 & .131 & .180 & .159 & .761 \\
\hline ICT in & -.008 & -.202 & .383 & 1.044 & .886 & -.006 & -.141 & .244 & .596 & .506 \\
\hline $\begin{array}{l}\text { Price compet. } \\
\text { in } T \& T \text { ind }\end{array}$ & .137 & -1.193 & -1.449 & -1.696 & .020 & .063 & -.397 & -.480 & -.564 & .007 \\
\hline (Constant) & -6.190 & -1.542 & -1.144 & -.278 & -3.539 & & & & & \\
\hline \multicolumn{11}{|c|}{ C. Human, cultural, and natural resources } \\
\hline HR & .727 & 2.469 & 3.025 & 2.612 & -2.151 & .272 & .670 & .759 & .684 & -.563 \\
\hline $\begin{array}{l}\text { Affinity for } \\
\text { T\&T }\end{array}$ & -.466 & .900 & .727 & .806 & 1.738 & -.257 & .489 & .397 & .440 & .949 \\
\hline Natural res. & -.380 & -.320 & -.200 & -.092 & -.038 & -.289 & -.235 & -.146 & -.066 & -.027 \\
\hline Cultural res. & .679 & .777 & .612 & \begin{tabular}{|l|}
.740 \\
\end{tabular} & .414 & .962 & .918 & .754 & .852 & .477 \\
\hline (Constant) & -3.140 & 19.423 & -21.21 & -20.28 & 1.350 & & & & & \\
\hline
\end{tabular}

(Source: our research results)

For 2011 (Table 4), the following pillars discriminated better: for EU members or non-members of EU: environment sustainability, ground transport infrastructure and cultural resources; for ex-communist/democratic countries: environment sustainability, air transport infrastructure and human resources; for developed/developing countries: safety and security, air transport infrastructure and human resources; for East/Central/West countries: environment sustainability, health and hygiene, air 
Manuela Rozalia Gabor, Mihaela Kardos, Nicoleta Cristache,Marian Nastase, Ioan-Radu Petrariu

transport infrastructure, tourism service infrastructure, human resources, affinity for travel and tourism.

Table 5. Standardized and Unstandardized Canonical Discriminant Function Coefficients for TTCI 2019

\begin{tabular}{|c|c|c|c|c|c|c|c|c|c|c|}
\hline \multirow{3}{*}{ Variables } & \multicolumn{5}{|c|}{$\begin{array}{l}\text { Canonical Discriminant Function } \\
\text { Coefficients }\end{array}$} & \multicolumn{5}{|c|}{$\begin{array}{c}\text { Standardized Canonical Discriminant } \\
\text { Function Coefficients }\end{array}$} \\
\hline & \multirow{2}{*}{ 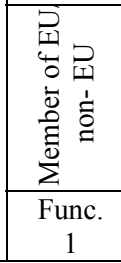 } & \multirow{2}{*}{ 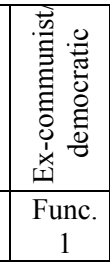 } & \multirow{2}{*}{ 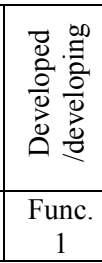 } & \multicolumn{2}{|c|}{ 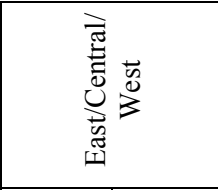 } & \multirow{2}{*}{ 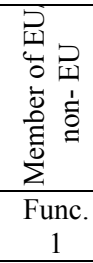 } & \multirow{2}{*}{ 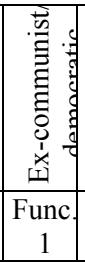 } & \multirow{2}{*}{ 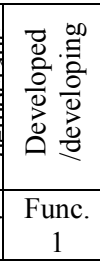 } & \multicolumn{2}{|c|}{ 苞 } \\
\hline & & & & $\begin{array}{c}\text { Func. } \\
1 \\
\end{array}$ & $\begin{array}{c}\text { Func. } \\
2 \\
\end{array}$ & & & & $\begin{array}{c}\text { Func. } \\
1 \\
\end{array}$ & $\begin{array}{c}\text { Func. } \\
2\end{array}$ \\
\hline \multicolumn{11}{|c|}{ A. Enabling Environment } \\
\hline $\begin{array}{l}\text { Business } \\
\text { environment }\end{array}$ & -1.037 & .447 & -.044 & -.699 & 1.434 & -.637 & 226 & -.022 & -.351 & .721 \\
\hline Safety\&secur & .463 & -1.088 & -.159 & -.014 & -.136 & .195 & .467 & -.063 & -.006 & -.054 \\
\hline Health \& hyg & .666 & -1.023 & -.654 & -.872 & 1.306 & .242 & .398 & -.252 & -.335 & .503 \\
\hline $\begin{array}{l}\text { HR \& labour } \\
\text { market }\end{array}$ & -1.879 & .594 & 1.200 & -.018 & 2.776 & -.849 & 220 & .406 & -.006 & .963 \\
\hline ICT readiness & 3.489 & 2.234 & 1.961 & 3.285 & -2.787 & 1.729 & .004 & .795 & 1.301 & -1.104 \\
\hline (Constant) & -11.975 & -4.759 & -11.634 & -9.319 & -12.504 & & & & & \\
\hline \multicolumn{11}{|c|}{ B. T \& T Policy and Enabling Conditions } \\
\hline $\begin{array}{l}\text { Prioritization } \\
\text { of T\& T }\end{array}$ & -.011 & -.764 & -.675 & -.285 & -.181 & -.007 & .396 & -.355 & -.162 & -.103 \\
\hline Int Openness & 2.425 & -.738 & -.565 & -.663 & 1.033 & 1.105 & .381 & -.292 & -.334 & .520 \\
\hline Price compet & .818 & 2.041 & 2.154 & 1.943 & 1.580 & .531 & 866 & .838 & .761 & 619 \\
\hline Env. sustain & .511 & .563 & .163 & -.419 & 1.436 & .285 & 309 & .085 & -.202 & .692 \\
\hline (Constant) & -15.697 & -6.463 & -6.220 & -3.923 & -17.847 & & & & & \\
\hline \multicolumn{11}{|c|}{ C. Infrastructure } \\
\hline Air trans infr & -.606 & 1.451 & 1.167 & 1.112 & -1.098 & -.656 & 844 & .760 & .726 & -.717 \\
\hline $\begin{array}{l}\text { Ground \& } \\
\text { port infrastr }\end{array}$ & 1.358 & .404 & .581 & .673 & .680 & 1.078 & 306 & .423 & .472 & .477 \\
\hline $\begin{array}{l}\text { Tourist } \\
\text { service infras }\end{array}$ & .570 & .230 & .265 & .259 & .918 & .454 & 168 & .192 & .185 & .654 \\
\hline (Constant) & -6.426 & -8.300 & -8.172 & -8.328 & -3.515 & & & & & \\
\hline \multicolumn{11}{|c|}{ D. Natural and Cultural Resources } \\
\hline Natural res & .341 & -.402 & -.256 & -.230 & 1.443 & .310 & .368 & -.233 & -.209 & 1.310 \\
\hline $\begin{array}{l}\text { Cultural res \& } \\
\text { bus travel }\end{array}$ & .507 & .886 & .815 & .814 & -.509 & .768 & .210 & 1.139 & 1.125 & -.703 \\
\hline (Constant) & -2.423 & -1.179 & -1.434 & -1.510 & -3.031 & & & & & \\
\hline
\end{tabular}

(Source: our research results)

For 2019 (Table 5), the following pillars discriminated better: for $E U$ members or non-members: ICT readiness, international openness, ground and port transport infrastructure and cultural resources; for ex-communist/democratic countries and for developed/developing countries: ICT readiness, price competitiveness, air transport infrastructure and cultural resources; for East/Central/West countries: ICT readiness, human resources and labor market, 
Dynamic Analysis of Tourism Competitiveness of the European Countries Based on Discriminant Statistical Analysis

price competitiveness, environment sustainability, air transport infrastructure, tourism service infrastructure, cultural and natural resources.

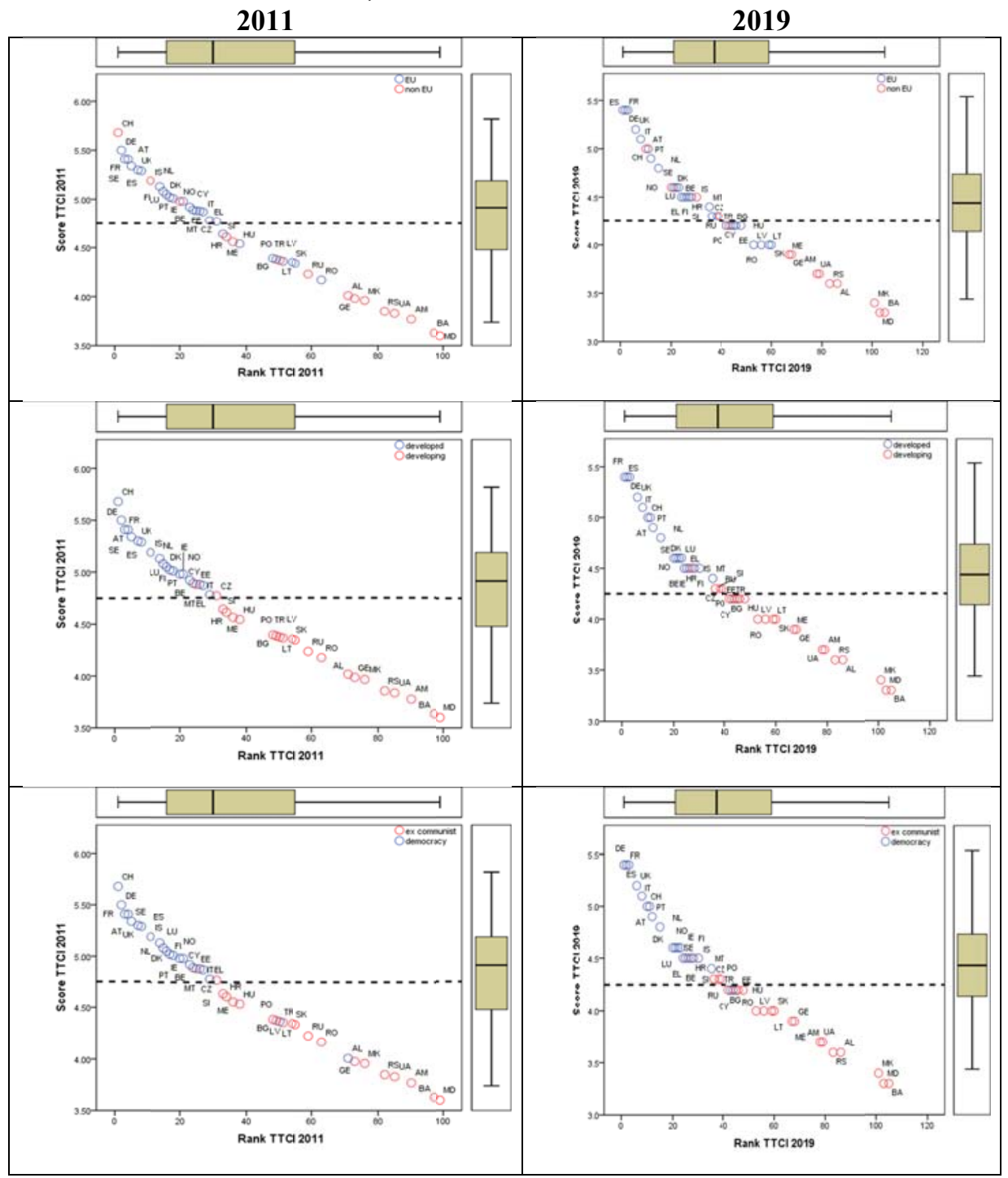


Manuela Rozalia Gabor, Mihaela Kardos, Nicoleta Cristache,Marian Nastase, Ioan-Radu Petrariu

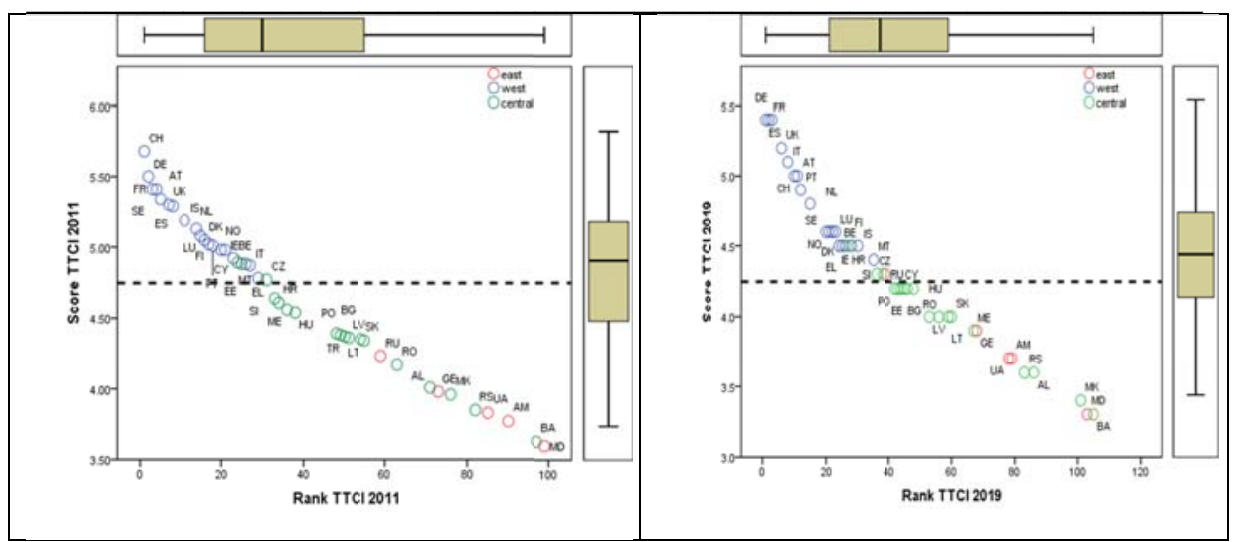

Figure 2. The distributions of all 42 European countries on the TTCI rank and TTCI score for 2011 and 2019

(Source: our research results)

Figure 2 presents the distributions of all 42 European countries on the TTCI rank and TTCI score for 2011 and 2019 according to the research groups. The average scores for 2011 is 4.7 and for 2019 is 4.3 (the dotted lines in Figure 2). Based on these graphical representations and the classification results from SPSS there are some important aspects to consider. For EU members or non-members, there are non-member countries of EU positioned up to average, but these countries are developed and also Western European countries such as Switzerland, Island, Norway in 2011 and 2019. In 2019 a good position is also for Turkey and Cyprus. For the group of developed/developing countries: the developing countries Czech Republic and Estonia for 2011 and Slovenia, Russian Federation, Estonia, Turkey and Croatia for 2019 are positioned up to average. For the group excommunist/democratic countries: the ex-communist countries the Czech Republic and Estonia for 2011 and Czech Republic, Slovenia, Poland and Croatia for 2019 are positioned near to developed countries, up to average. For the group East/Central/West European countries: for 2011 Cyprus, Malta and Czech Republic are positioned near the West European countries (up to average) and for 2019 the Russian Federation, Slovenia and Czech Republic have a good position, up to average.

\section{Conclusions and discussions}

Tourism industry is a vital driving force towards the alleviation of poverty and regional disparities, especially in emerging destination (Hanafiah et al., 2016a). The management of tourism destination is very important in developing tourism, investments, and exports and finally in developing a country or a city. Linked to these aspects, a simple analysis of the evolutions from Figure 1 emphasizes that in 2019 compared to 2011 some ex-communist countries or/and East European countries, e.g.: Russian Federation, Armenia, Croatia, Georgia, Bulgaria, Poland, 
Dynamic Analysis of Tourism Competitiveness of the European Countries Based on Discriminant Statistical Analysis

Romania, Slovak Republic, Ukraine, and Turkey rack higher, while non-EU members (Switzerland, Iceland), Nordic countries (Sweden, Denmark, Ireland, Finland, Latvia, Lithuania, Estonia) or countries from the ex-Yugoslavia (Montenegro, Macedonia, Bosnia \& Herzegovina, Serbia, Slovenia) or in their vicinity (Albania, Malta, Cyprus) rank lower.

The present results must be interpreted also considering the changes in the TTCI methodology between 2011 and 2019. For example, if in 2011 the ICT was considered a tourism and travel environment and infrastructure pillar, in 2019 it was an Enabling environment one and renamed in ICT readiness. The human resources pillar were part of Tourism \& travel human, cultural and natural resources (a resources) sub-index in 2011, while in 2019 it was renamed in human resources and labor market and became part of enabling environment sub-index, not only a resource. Moreover, the price competitiveness pillar became from 2011 a Tourism \& travel environment and infrastructure sub-index and in 2019 a Policy \& enabling conditioning sub-index.

Starting from the research results mentioned in Literature review section, we can consider that our results confirm the Khan et al. (2017) results. For all four groups of the European countries, the pillars of infrastructure discriminate better for both 2011 and 2019. More precisely, using discriminant analysis we found that the pillar ground transport infrastructure discriminates for the group of EU/nonEU members and air transport infrastructure discriminates better, significantly statistics, for all the rest of groups, e.g. East/West/Central countries, excommunist/democratic countries and developed/developing countries for both 2011 and 2019.

Also, our results emphasize other important dynamical changes of the TTCI analysis: when countries were grouped by ex-communist/democratic countries, developed/developing countries and East/Central/West European countries, for both 2011 and 2019, the pillar air transport infrastructure discriminates best. Moreover, if for 2011 the human resources pillar was a good discriminant for these three groups, for 2019 the cultural resources pillar was one of the best discriminants for all four groups of countries. In 2011 the cultural resource was a significant discriminant only for the group EU/non-EU members. In 2011, together with the air transport pillar, the environment sustainability pillar was a good discriminant for all the groups except the group of developed/developing countries. For 2019 the environment sustainability pillar discriminated only for the geographically positioned and only for the second function. For 2019, beside the ICT readiness, cultural resources, and air transport infrastructure the discriminant analysis emphasized another good discriminant for all groups (except the EU/non-EU members), the price competitiveness pillar. Our dynamic analysis results using discriminant analysis confirm the World Economic Forum 2019 Report statement that the strongest improvements come from the ICT readiness, price competitiveness and air transport infrastructure pillars (TTCI Report, p. 34). 
Manuela Rozalia Gabor, Mihaela Kardos, Nicoleta Cristache,Marian Nastase, Ioan-Radu Petrariu

In conclusion, we consider that our research results emphasize - through the discriminant analysis - and confirm the remarks of the Future Brands and their latest Country Brand Report (2016) that people strongly perceive aspects related to life quality, value systems and business potential, as they do for culture, history, tourism and "Made in" expertise. According to this report, among the 22 countries qualified as "country brand", 13 countries are from Europe. If we analyze the position of Romania compared with other ex-communist or developing countries, we found that it occupies position 62 and it is overcome by the Czech Republic (29), Poland (45), Estonia (47), Hungary (56), all ex-communist former countries that have begun an intense promotion of the country brand and a good tourism destination management (Future Brands, 2016).

We also consider some limitations of the results, as follows:

- in the construction of the TTCI index, the efficiency of tourism destination is the main objective, not other important aspects like innovation (Mendola \& Volo, 2017) or the tourists' motivation for travel;

- also, according to Kester and Croce cited by Hanafiah et al. (2016a) the TTCI tends to rank advanced economies higher than countries in lower stages of development;

- TTCI does not represent a country's actual tourism performance because TTCI Report treats all sub-indices/pillars with equal weights (Hanafiah et al., 2017);

- TTCI is more a systematic collection of data, not a model that encourages inferential analysis (Croes, 2013).

It is also important to mention that many tourism studies excluded crucial external aspects such as globalization (Hanafiah et al., 2016b) affecting more the developing countries that the developed ones. More important for the new millennium, seif and security has been identified as one of the five global forces that would drive tourism industry (Vengesayi, 2003) and is an important consideration in tourist destination choice.

Tourism and its performance as well as competitiveness depend on the cooperation of different sectors, private and public, and the cooperation of the providers of tourism services (Mazurek, 2014).

This paper fills in previous results (Gabor, Oltean \& Conțiu, 2012; Gabor $\&$ Oltean, 2017) and using the means of discriminant analysis details and points out other aspects related to measuring and ranking tourism competitiveness of European countries.

In future extended research, we intent to introduce new variables/discriminant (i.e. innovative driven economy/efficiency driven economy, etc.) and to make a dynamic analysis, i.e. 2020 (the pandemic time) with a recent year with major political changes (i.e. Great Britain leaving the EU in 2021). 
Dynamic Analysis of Tourism Competitiveness of the European Countries Based on Discriminant Statistical Analysis

\section{REFERENCES}

[1] Blanke, J. \& Chiesa, T. (2011), The Travel and Tourism Competitiveness Repost 2011. Geneva: World Economic Forum;

[2] Cracolici, F., Nijkamp, P. \& Rietveld, P. (2008), Assessment of Tourist Competitiveness by Analysing Destination Efficiency. Tourism Economics, 14, 325-342;

[3] Croes, R. (2013), Evaluation of Tourism Competitiveness and its Effects on Destination Management: Making a Difference in Costa Rica?. Dialogos Revista electronica de historia, 115 - 133;

[4] Crotti, R. \& Misrahi, T. (2015), The Travel \& Tourism Competitiveness Report 2015. Growth through Shocks. Geneva: World Economic Forum; [5] Das, J. \& Dirienzo, C.E. (2010), Tourism Competitiveness and the Role of Diversity: A Cross-Country Analysis. In V. Mladenov \& Z. Bojkovic (Eds.) Latest Trends on Cultural Heritage and Tourism (pp. 19-27). Corfu: WSEAS Press; [6] Dias, J. G. (2017), Environmental Sustainability Measurement in the Travel \& Tourism Competitiveness Index: An Empirical Analysis of Its Reliability. Ecological indicators, 73, 589-596;

[7] Fayed, H. \& Fletcher, J. (2002), Report: Globalization of Economic Activity: Issues for Tourism. Tourism Economics, 8, 207-230;

[8] Future Brands (2016), Country Brand Index 2014-15. Availalble online: https://www.futurebrand.com/uploads/Country-Brand-Index-2014-15.pdf;

[9] Gabor, M. R. \& Oltean, F. D. (2017), What Macroeconomic Index Differentiates or Similar the European Tourism Competitiveness? A Multimethod Analysis. North Economic Review, 1, 201-207;

[10] Gabor, M.R. (2016), Analiza si inferenta datelor de marketing. Bucharest: C.H. Beck;

[11] Gabor, M.R., Conțiu, L.C. \& Oltean, F.D. (2012), A Comparative Analysis Regarding European Tourism Competitiveness: Emerging versus Developed Markets. Procedia Economics \& Finance, 3, 362-367, DOI:10.1016/S22125671(12)00165-7;

[12] Gabor, M.R. (2010), Explanatory Methods of Marketing Data Analysis Theoretical and Methodological Considerations. Management - Marketing, 1, $373-384$;

[13] Gooroochurn, N. \& Sugiyarto, G. (2005), Competitiveness Indicators in the Travel and Tourism Industry. Tourism Economics, 11, 25-43;

[14] Hanafiah, M.H., Hemdi, M.A., Ahmad, I. \& Darson, D. (2016a), Tourism Core and Created Resources: Assessment on Travel and Tourism Competitiveness Index (TTCI) Ranking and Tourism Performance. In: Radzi et al. (Eds.) Heritage, Culture and Society (pp. 383 - 388). London: Taylor \& Francis Group; 
Manuela Rozalia Gabor, Mihaela Kardos, Nicoleta Cristache,Marian Nastase, Ioan-Radu Petrariu

[15] Hanafiah, M.H., Hemdi, M.A. \&. Ahmad, I.(2016b), Tourism Destination Competitiveness: Towards a Performance-based Approach. Tourism Economics, 22, $629-636$;

[16] Hanafiah, M.H., Hemdi, M.A. \&. Ahmad, I.(2017), The influence of Tourism Core Resources on Travel and the Tourism Competitiveness Index and Tourism Performance. In A. Saufi et al. (Eds.) Balancing Development and Sustainability in Tourism Destinations, (pp. 377 -384). Singapore: Springer. DOI: 10.1007/978-981-10-1718-6 34;

[17] Khan, S.A.R., Qianli, D., SongBo, W., Zaman, K. \& Zhang, Y. (2017), Travel and Tourism Competitiveness Index: The Impact of Air Transportation, Railways Transportation, Travel and Transport Services on International Inbound and Outbound Tourism. Journal of Air Transport Management, 58, 125134;

[18] Lee, S. (2015), Research Note: Quality of Government and Tourism Destination Competitiveness. Tourism Economics, 21, 881-888;

[19] Mazanec, J. A. \& Ring, A. (2011), Tourism Destination Competitiveness: Second Thoughts on the World Economic Forum Reports. Tourism Economics, 17, 725-751;

[20] Mazurek, M. (2014), Competitiveness in Tourism - Models of Tourism Competitiveness and Their Applicability: Case Study Austria and Switzerland. European Journal of Tourism, Hospitality and Recreation, Special issue, 73-94; [21] Mendola, D. \& Volo, S. (2017), Building Composite Indicators in Tourism Studies: Measurements and Applications in Tourism Destination Competitiveness. Tourism Management, 59, 541-553;

[22] Omkar, J., Neelam, P.C. \& Lincoln, L. R. (2017), The Influence of Sociopolitical, Natural, and Cultural Factors on International Tourism Growth: A Cross-country Panel Analysis. Environment Development and Sustainability, 19, 825-838;

[23] Sanchez, A.G. \& Lopez, D.S. (2015), Tourism Destination Competitiveness: The Spanish Mediterranean Case. Tourism Economics, 21, 1235-1254. DOI: 10.5367/te.2014.0405;

[24] Spircu, L. Calciu, M. \& Spircu, T. (1994), Analiza datelor de marketing. Bucharest: $A L L$;

[25] UNWTO (2018), Tourism Highlights 2018 Edition. Available online: https://www.e-unwto.org/doi/pdf/10.18111/9789284419876. 